\title{
Théologiques
}

\section{Jewish-Christian Dialogue under the Shadow of the Israeli-Palestinian Conflict}

\section{Gregory Baum}

Volume 11, numéro 1-2, automne 2003

Juifs et chrétiens. L’à-venir du dialogue.

URI : https://id.erudit.org/iderudit/009532ar

DOI : https://doi.org/10.7202/009532ar

Aller au sommaire du numéro

Éditeur(s)

Faculté de théologie de l'Université de Montréal

ISSN

1188-7109 (imprimé)

1492-1413 (numérique)

Découvrir la revue

Citer cet article

Baum, G. (2003). Jewish-Christian Dialogue under the Shadow of the

Israeli-Palestinian Conflict. Théologiques, 11(1-2), 205-221.

https://doi.org/10.7202/009532ar d'utilisation que vous pouvez consulter en ligne.

https://apropos.erudit.org/fr/usagers/politique-dutilisation/ 


\title{
Jewish-Christian Dialogue under the Shadow of the Israeli-Palestinian Conflict
}

\author{
Gregory Baum \\ Religious Studies \\ McGill University
}

Prior to World War II, Jewish religious thinkers who moved beyond the tradition of Orthodoxy were in dialogue with modern culture, including dialogue with Christian thinkers who were also searching new religious responses to the challenge of modernity. Paul Tillich's "Circle of Religious Socialists," founded after World War I, included Christians and Jews, Martin Buber among them. Yet even after World War II, the young German-Canadian philosopher Emil Fackenheim saw himself as an ally of Christian theologians in a joint effort to communicate the word of God to a society that had become secular. He gladly acknowledged an affinity of his theological approach with neo-orthodox Christian thought. Yet in 1967, gripped by the fear that Israel might be destroyed, he assigned the Holocaust a central position in his thinking. He heard God's commanding voice speaking out of the Shoah giving Jewish men and women a new commandment: to struggle for their collective survival so that Hitler would not be granted a posthumous victory. "Never again shall the Jewish people be humiliated and destroyed!" Fackenheim now took up dialogue with Christian thinkers in a new key, demanding not only repentance over the Church's ancient anti-Jewish discourse, but also wholehearted support for the State of Israel, the concrete symbol of Jewish survival and security in the world ${ }^{1}$.

1. G. Baum, "Fackenheim and Christianity," in L. Greenspan and G. Nicholson, eds., Fackenheim: German Philosophy and Jewish Thought, Toronto, University of Toronto Press, 1992, p. 176-202 (here p. 177). 
I was ill at ease with Emil Fackenheim's mature theology. We had been friends. I met him in the 1940s in Hamilton, Ontario, where he worked as a rabbi and I was a student at McMaster University. It seemed to me that in 1967 my friend responded to the Holocaust by focusing on the struggle for Jewish survival and the security of the Jewish State, while turning his back on the oppression and the violence inflicted upon other peoples. I was more impressed by the American scholar and rabbi, Irving Greenberg, who responded to the Holocaust by saying "Never again!”, meaning that never again shall the Jewish people or any other people be humiliated and destroyed. On this basis, Greenberg supported the Jewish State and, at the same time, opposed the war in Vietnam and criticized the American Orthodox Rabbinate for its silence. Greenberg also argued that with the foundation of the State of Israel, Jews find themselves in a new historical situation. Since they are now able to exercise power, which they were unable to do in the past, they are presently obliged to engage in ethical reflection on the right use of power $^{2}$. I preferred Greenberg's theology to that of Fackenheim.

\section{Learning from Jewish-Christian Dialogue}

Dialogue between Jews and Christians has made an important contribution to the self-understanding of Christianity. By dialogue I refer not only to round table discussions between Jews and Christians, but also and more especially to literary exchanges between them. Jews and Christians have begun to read one another's religious reflections. Jews helped the Church to enter the painful process of becoming aware of its ancient anti-Jewish rhetoric. I am thinking especially of Jules Isaac who participated at the Seelisberg Conference in 1947 that recognized the anti-Jewish discourse in the New Testament, produced a set of guidelines for correcting this baneful inheritance, and started a movement in the Christian Church to redefine its relationship to the Synagogue and the Jewish

2. I. Greenberg presented his theological response to the Holocaust at a JewishChristian symposium, held in 1974 in New York and published in E. Fleischner, ed., Auschwitz: Beginning of a New Era, New York, KTAV Publishing House, 1977, p. 7-53. See also G. BAum, "Theology after Auschwitz: A Conference Report," The Ecumenist, 12 (July-August 1974) p. 65-80. 
people 3 . In the Catholic Church, this movement had an impact on the Vatican Council (1962-1965). The conciliar declaration Nostra Aetate introduced a new discourse on the Jews and their religion, recognized the ongoing validity of God's ancient covenant with the Jewish people, and called upon Catholics to engage in dialogue, cooperation and friendship with Jews. Similar processes occurred in other Christian Churches. A remarkable statement on Christian respect for Jews and Jewish religion has recently been produced by the United Church of Canada ${ }^{4}$.

Dialogue with Jews had a multiple impact on Christian theology. We, who spoke so confidently of redemption, became aware of the unredemption dwelling among us and retrieved the eschatological yearning. We, who focused on the salvation and sanctification of souls, recovered the social message inscribed in the Scriptures and linked faith in Jesus Christ to commitment to social justice. We, who desired to bracket the body and live for the soul, became reconciled to ourselves as bodies unashamedly, in awe of the physical universe around us. In this evolution of Christian self-understanding, dialogue with Jewish religious thought played a considerable part. Even going further, some Christian thinkers who had seen in the order of the universe a sign of God's existence had their vision shattered by the Holocaust and agreed with Rabbi Greenberg that this event had spelled the end of "untroubled theism." Christian theologians anguished with Jewish religious thinkers in what sense it is still possible to think of God's omnipotence and believe in divine Providence ${ }^{5}$.

Our changed relationship to Jews and the awareness of our inherited anti-Judaism has had a profound affect on our study of the Scriptures, our theology of redemption, our catechetical instructions and the preaching on Sunday morning. I was not surprised that reacting to Mel Gibson's film on the passion of Christ, several Churches reminded their members that the story of Christ's suffering had been used over the centuries to stir up hatred for the Jews and that it was shameful and irrational to put the

3. On J. Isaac, see the French review Sens, 4 (1977); on the Seelisberg Conference, see Sens, 10 (1998).

4. “Bearing Faithful Witness" (August 2003), on the Web: <www.united-church.ca/ bfw/finalstatement.shtm>.

5. G. Baum, "The Idea of Providence after World War II," The Ecumenist, 39 (Winter 2002) p. 6-13. 
blame for the passion of Christ on an entire people. Again, the United Church of Canada published an excellent theological statement on this issue $^{6}$.

\section{Christian Reactions to the State of Israel}

What has been the reaction of Christians to the State of Israel? It is my impression that in Europe and North America the great majority of Christians, repenting of Christianity's anti-Jewish heritage, became strong supporters of the new Republic. Yet there were also conservative Christians, especially at the Vatican, who believed that the expulsion of the Jews from Jerusalem after the Roman conquest in 70 CE was God's judgement on Israel after her refusal to receive Jesus as their Messiah. These Christians held that the Jewish people may not return to Jerusalem and, therefore, that the foundation of the State of Israel was contrary to the divine will. Christians in the Middle East and some Western Christians in solidarity with them regarded the foundation of the Jewish State as the continuation of previous colonial oppression preventing the local population from political self-determination.

The most ardent defenders of the Jewish State were theologians and activists in the Churches who loved their Jewish dialogue partners and passionately wrestled against Christian anti-Semitism. The literature they produced affected the American and Canadian Catholic bishops and shaped the public statements they made in support of Israel. The North American bishops urged the Vatican to give official recognition to the Jewish State, an event that happened very late, in 1993.

I remember that in the early seventies I gave a talk in Toronto, later published in the American review The Christian Century, in which I scolded a Christian journalist for depicting the Jewish State as oppressor of the Palestinian nation. I argued that because of their vilification of the Jews over the centuries, Christians had lost the right to teach ethics to the Jewish people. At that time, Johann Baptist Metz, the important German Catholic theologian, insisted that "Christian theology may never turn its back upon Auschwitz," and defended the State of Israel as "a house against death" in response to accusations uttered from within the German political Left.

6. See on the Web: <www.united-church.ca/bfw/home.shtm>. 
After the start of the first Intifada in 1988, the mood in the Churches began to change. This is how I started an article written at that time:

The North American Churches have on the whole been relatively silent on the plight of the Palestinian people. Church groups in Canada and the US have hesitated to give strong expression of their solidarity with the Palestinians in their quest for a homeland. Thus Churches find themselves in a dilemma. The topic is so delicate because it is situated in the intersection of two major trends in contemporary church life, both of which spring from the same theological root $^{7}$.

What are these two major trends? The Christian Church in the West has been wrestling with a twofold guilt, first the guilt over its ancient anti-Jewish discourse, the contribution it made to modern anti-Semitism and its coward silence during the Holocaust, and second, the guilt over its past identification with European empires and their colonial conquests. Not only did the Churches regard these conquests as providential, opening the door to the spread of the Gospel, they also assumed the superiority of European civilization and tended, with some remarkable exceptions, to see their mission as the promotion of the White Man's culture. In Canada, the Churches have made the painful discovery of the ambiguity of the missionary efforts among the Native Peoples. The Church's remorse over its anti-Jewish rhetoric and its contempt for Jewish religion is therefore accompanied by the Church's remorse over its identification with empire and its spread of the White Man's religion. As a consequence, the Church is deeply committed to "the Third World," i.e. to the efforts of the colonized nations to free themselves from foreign domination and create social conditions of greater justice. To express this new solidarity, some authors have begun to speak of the Third Church ${ }^{8}$.

The Churches of the West have become aware that the frontiers of the new nations in Africa and Asia were drawn by the colonial powers indifferent to the natural cohesion produced by a common ethnic and linguistic inheritance. Iraq, for instance, was created by the British Empire as a hotchpotch of different communities, formerly part of the Ottoman Empire, that had nothing in common with one another. The

7. G. BAum, "The Churches, Israel and the Palestinians," The Ecumenist, 27 (Nov.Dec. 1988) p. 1-6.

8. W. Bühlmann, The Coming of the Third Church, Maryknoll, NY, Orbis Books, 1977. 
divisions and conflicts in many parts of Asia and Africa are derived from their colonial past. Since the Third Church, troubled by its former loyalties, supports the self-determination of the formerly colonized peoples, it has spontaneous sympathy for the Palestinians.

Jews suffered discrimination in the European empires and thus were not in any way associated with military conquest and colonization. There is no reason for Jews to share the remorse of the Churches over their past loyalties nor their deep concern for the liberation of the Third World and the Native Peoples. Many Jews support the struggle for greater justice in these parts, yet they don't do this-as do the Churches-as acts of reparation.

After the first Intifada in 1988, the Churches began to speak of a twofold solidarity binding them to the State of Israel and the Palestinian people. They supported the security of the Jewish State in safe borders and the creation of a Palestinian State on a contiguous territory. Some American Evangelical Churches lobbied in favour of the Jewish State and a council called "The Churches for Middle East Peace" lobbied in favour of Palestinian self-determination, yet most of the Churches pleaded more even-handedly for a political, non-violent solution of the present conflict.

\section{After the Second Intifada}

The second wave of the Intifada after Ariel Sharon's visit on the Temple Mount on September 28, 2000, and the military reaction to it by the State of Israel caused renewed anguish among the Western Churches. The leaders of the Canadian Churches felt that they had to speak to this new situation. Relying on the research done over the years by ecumenical church groups, these leaders composed a draft statement destined for publication in Advent 2000, addressed to the Churches in the Middle East as well as to Christians in Canada. For the sake of "transparency", the church leaders decided to send the draft to the Canadian Jewish Congress (CJC). They did not expect to get a reply that pleaded with them not to publish the statement as drafted. The church leaders complied with these wishes, postponed the publication of the statement, and published it in a modified form in January $2001^{9}$.

9. "Churches water down Mid-East policy," Ottawa Citizen (January 6, 2001); "Catholic Church's New Jewish Initiative Put to Test in Mid-East Statement” (January 28, 2001). 
What were the objections raised by the CJC? The draft statement was accused of being one-sided, looking at the Middle East conflict only from the side of the Palestinians and being silent about Israel's internationally recognized right to a peaceful existence within safe borders. "We deeply regret your decision not to walk even one inch in the Jewish people's shoes, especially when in Canada you have sought positive Christian-Jewish relations." According to the CJC, the Christian draft statement did not adequately acknowledge the violence committed by the Palestinians and simply assumed that the origin of the conflict was the fault of Israel. The CJC regretted that the draft spoke of Israeli settlement on Palestinian territory as "built on confiscated land" and insisted that a just peace treaty required the removal of these settlements from the West Bank and Gaza. The CJC was also offended that the draft statement gave explicit support to UN Security Council Resolution 1322 of October 7,2000, criticizing Israel for the use of excessive violence and calling for the withdrawal of Israel from the occupied territories.

The Canadian church leaders accepted the demands made by the CJC. They could have argued that the position adopted in their draft statement corresponded in several points with the Canadian government's policy on the Middle East. Canada supports the security, wellbeing and rights of Israel as a legitimate, independent State. Yet the Canadian government does not recognize permanent Israeli control over the territories occupied in 1967 (the Golan Heights, the West Bank, East Jerusalem and the Gaza Strip) and opposes all unilateral actions intended to predetermine the outcome of negotiations, including the establishment of settlements in the territories and unilateral moves to annex East Jerusalem and the Golan Heights. Moreover Canada supported the UN Security Council Resolution 1322.

Yet the Canadian church leaders, deeply attached to Jewish-Christian friendship, altered their draft and produced an even-handed statement that recognized the right of Palestine and Israel to exist in peace and security and demanded that the spiral of violent protest and violent repression give way to non-violence and negotiations. The final statement still demands, even in less specific terms, "the speedy implementation of the relevant United Nations Security Council resolutions, the withdrawal of Israel from settlements in Gaza and the West Bank and the provision of territorial integrity for a Palestinian state ${ }^{10}$."

10. "Eleven Canadian Christian Leaders' Call for Peace with Justice in the Middle East (5 January 2001)," on line at <www.ccc-cce.ca/english/justice/middleeast.htm>. 
Jews in North America are, on the whole, deeply offended by the demand that Israel end the occupation, withdraw to the Green Line and order the settlers to return to the Jewish State. This demand, they argue with the Canadian Jewish Congress, puts the entire blame for the present conflict on Israel, without recognizing the threats to its very existence. Authors or speakers who call for the end of the occupation and the return of the settlers can find themselves designated as anti-Semites. It is of course quite true that people prejudiced against Jews may criticize Israel to express their personal bias in an acceptable form. Anti-Zionism may be a cover for anti-Semitism. But there are people, church people among them, who have proven their loyalty to Jews and who now express their opposition to the occupation and the settlements. To designate them as anti-Semitic is not only unjust but also unfair since there is no way a person accused of this prejudice can demonstrate his or her innocence. Such is the mood in society at this time that people hesitate to reveal their critical reflections on the Israeli-Palestinian conflict. They prefer to remain silent; yet they feel frustrated and wonder if they are not cowardly dishonest.

The shadow of the Israeli-Palestinian conflict also falls on JewishChristian dialogue in North America. On both sides the dialogue partners feel safer if there is no mention of the Middle East. Since Jewish public opinion in North America is largely unanimous in its support of the Israeli policy on the occupation and the settlements, it is better to avoid the topic. To strengthen solidarity between Catholics and Jews, a meeting took place in New York on January 19, 2004 that brought into conversation eight Cardinals from different continents and the important leaders of the international Jewish community. The participants thought that the meeting was a great success. The Middle East conflict was not mentioned.

On Dec. 8, 2003, the leaders of the Canadian Churches published a letter in which they condemn the recent manifestations of anti-Semitism in Canada and express their solidarity with the Jewish people on theological grounds ${ }^{11}$. They again express their sorrow over the hostility to Jews mediated in the past by Christian teaching and remind Christians

11. "A church leaders' letter against anti-Semitism to the churches of Canada the Jewish community in Canada, and to all people of good will...”, on the Web: <www. jcrelations.net/en/?id=2143>. 
of the indebtedness of the Church to the tradition of Israel. "We declare our unqualified gratitude for the gifts of the Jewish people to world civilization in general and Canadian society in particular." The church leaders omit any reference to the Middle East conflict. Does solidarity with the Jewish people imply support for Israeli occupation of Palestine? Or may Christians express their objection to the occupation and the settlements, even if ardent defenders of these policies call them anti-Semitic?

\section{The Inter-Jewish Debate}

What is less known in North America is that there are Jewish groups and individual Jewish voices that offer strong support for the State of Israel but are critical of its policies toward the Palestinians. I mentioned Rabbi Greenberg at the beginning of this article. There are many Jewish peace and justice groups in Israel and a few Jewish voices in North America that advocate the withdrawal of Israel to the Green Line and reconciliation with the Palestinians, but their efforts are not reported in the mass media. Their books are brought out by small publishing companies that publish radical literature that is not reviewed in the major journals. Exceptions are two recent collections of essays and statements, Wrestling with Zion: Progressive Jewish-American Responses to the Israeli-Palestinian Conflict ${ }^{12}$ and Prophets Outcast: Dissenting Jewish Writings about Zionism and Israel ${ }^{13}$.

It is my impression that in France the inter-Jewish debate in regard to the Middle East conflict is carried out in the public media. Here are two examples. In Le Point of Oct. 3, 2003, we read a debate between two Jewish intellectuals, Rony Brauman and Alain Finkielkraut, the former claiming that one cannot criticise the State of Israel without being accused of anti-Semitism and the later denouncing the emergence of a new anti-Semitism disguised as a critique of the Jewish State.

The other example is the publication in 2003 of La prison juive by the Jewish intellectual Jean Daniel, well-known editor of Le Nouvel

12. T. Kushner and A. Slomon, eds., Wrestling with Zion: Progressive Jewish-American Responses to the Israeli-Palestinian Conflict, New York, Grove Press, 2003.

13. A. Shatz, ed., Prophets Outcast: Dissenting Jewish Writings about Zionism and Israel, New York, Nation Books, 2004. 
Observateur, who laments the worsening of the Israeli-Palestinian conflict caused, he thinks, by the invocation of God's name. Jewish settlers believe that God gave them the land, and Palestinian suicide bombers trust that God will embrace them as holy martyrs. Faith in an Absolute, whether Jewish, Christian or Muslim, Daniel argues, is a spiritual prison making believers unable to negotiate and arrive at a compromise, which is the only way to peace.

In Israel, the inter-Jewish debate over the occupation is very lively. The Internet provides websites of a series of Jewish peace-and-justice organisations, some of which welcome Palestinian members. The North American press provides no information regarding these groups. Nor were they known by my Jewish friends, with whom I shared my discovery. These are the groups: Rabbis for Human Rights, $\mathrm{O} z$ VeShalom (a peace-oriented Orthodox network), Israeli Committee Against House Demolitions, Bat Shalom (a woman's movement for peace), Coalition of Women for a Just Peace, Gush Shalom (a grassroots movement founded by Uri Avneri), B'Tselem (Israeli Centre for Human Rights in the Occupied Territories), Israeli Council for Israeli-Palestinian Peace (ICIPP), Peace Now, Israel/Palestine Center for Research and Information, Minerva Centre for Human Rights.

Allow me to cite the Principles of Faith spelled out by the Rabbis for Human Rights and their expression of loyalty to Israel's Declaration of Independence.

We, members of Israeli Rabbis For Human Rights, affirm [these principles] in our daily prayers and blessings:

\section{God and Human Beings}

God is sovereign over the universe. All humankind is created in God's image and is an active partner with God in perfecting the world. (Shabbat 10a, 119b).

\section{Abraham}

When God chose our father Abraham, God promised, "All the families of the earth shall bless themselves by you" (Gen. 12:2) and that he would instruct his children and posterity "to keep the way of the Lord by doing what is just and right" (Genesis 18:19). As descendants of Abraham, we must fulfill his legacy of "compassion, generosity and sensitivity" 
(Yevamot 79b). In accordance with our Torah tradition, the world will declare in admiration, "what great nation has laws and rules as just as all this Teaching that I set before you this day?" (Deut. 4:8).

\section{Torah}

The essence of Torah, as summarized by Hillel: "What is hateful to you, do not do to others," reflects the historic experience and ethical consciousness of the Jewish people. Both this historic experience and ethical consciousness must sensitize us to defend the right of all who dwell among us. "When a stranger resides with you in your land, you shall not wrong him. The stranger who resides with you shall be to you as one of your citizens: you shall love him as yourself, for you were strangers in the land of Egypt: I am the Lord your God" (Lev. 19:33-34).

\section{Kiddush Hashem}

Exemplary conduct of Israel is a sanctification of God's name (Kiddush HaShem): shameful conduct is a defamation of God's name (Chilul HaShem).

\section{Preserving Life}

God's name is sanctified through the respect we show for the human worth and dignity of all God's creatures.

\section{Sanctity of Human Life}

Our Mishnah teaches: "Therefore was Adam created single, to teach you that the destruction of any person's life is tantamount to destroying a whole world and the preservation of a single life is tantamount to preserving a whole world" (Sanhedrin 4:5). And again in the words of Rabbi Akiva: "Beloved is Man who was created in (God's) image" (Pirkei Avot 3:18). In an ideal state, "We beat our swords into plowshares..." (Isaiah 2:4). With our concern for human dignity and the preservation of life, be they Jews or Arabs, we are deeply disturbed by and seek to remove excesses and abuses such as:

- Expropriation of land.

- Uprooting of trees.

- Demolition of homes.

- Torture through the use of "moderate physical or psychological pressure."

- Coercion and torture to extract confession or to incriminate others. 
- Bullying and humiliating, which is demoralizing both to perpetrator and victim: and we wish to save our children from the temptation to these vices.

- The exercise of double standards by, or the granting of relative immunity to those who wield political or military power and authority, in the pursuit of criminal proceedings in general, through delay, evasion, and protection.

- Shooting to kill when life is not in immediate danger.

- Collective punishment of "children for the sins of their parents" and "parents for the sins of their children."

- Imprisonment without trial in administrative detention.

- Removing the rights of residence through confiscation of identity cards.

- Sale of weapons to aggressive regimes.

- Undercover killings.

As Rabbis of Human Rights in Israel, we are committed to the principles stated in Israel's Declaration of Independence "to foster the development of the country for the benefit of all the inhabitants, based on freedom, justice and peace as envisaged by the prophets of Israel: to ensure complete quality of social and political rights to all its inhabitants, irrespective of religion, race, and sex: to guarantee freedom of religion, conscience, language, education and culture; to guard the holy places of all religions: and to be faithful to the principles of the Charter of the UN."

We pray to bring nearer the day for the fulfillment of the prophecy: "The remnant of Israel will not act iniquitously, nor speak falsely; neither shall there by found in their mouths the tongue of deceit" (Zephaniah 3:13); "When nation will not lift up sword against nation, and no longer train for war." (Isaiah 2:4) "Who is mighty? One who transforms one's enemy into one's friend". (Avot D'Rabbi Natan 23)

When I discovered the websites of these organisations in November 2000 , I was greatly impressed by the statements of their ethical principles, their analysis of the political situation in Israel and their practical engagement in demonstrations against government policies and actions of solidarity with Palestinians. I downloaded a series of reports and statements from each of these organisations, 150 pages in all, to which I added an introduction of 20 pages and a conclusion of 15 , in the hope 
of finding a publisher for the manuscript. I did not succeed. The manuscript was rejected by six publishers as too controversial.

In the conclusion of my study I noted that while these groups were not in agreement on all political issues, they were all Zionists, they were patriots, they loved their country. Yet they held that their country, by occupying another people, is betraying the Jewish ethical tradition that is to be an example to the nations. They argued that their commitment to social justice is not only for the sake of the unjustly-treated Palestinians, but also and especially for the sake of the Jewish State that is in danger of losing its identity and moral legitimacy-and of entering a phase of violence that may become self-destructive. These groups sorrow over the violence committed on both sides. They record the acts of violence and the terror committed by the State of Israel in the occupied territories, and they do the same for the acts of violence and terror committed by Palestinians against citizens of Israel.

The statements made by these groups and their public gestures are hardly ever reported in the North American media. Gush Shalom, the organisation directed by Uri Avneri, sends out e-mail messages on the activities of the Jewish peace-and-justice movements. In these messages, we hear of the repeated demonstration of Jewish Israelis protesting against the wall of separation that is presently being built.

Let me mention some of the North American Jewish centres committed to justice and peace that support the State of Israel, but are critical of its policies. These centres are in touch with the peace-and-justice groups in Israel.

The Shalom Center in Philadelphia, founded by Rabbi Arthur Waskow, brings Jewish tradition and spirituality to bear on issues of tikkum olam-pursuing peace, seeking justice, healing the earth and building community ${ }^{14}$. The Center works for peace between Israel and the Palestinian people. It provides a critical analysis of the political developments in Israel and reports the activities of the peace-and-justice groups in that country. The focus of the Center is spirituality. It tries to teach the Jewish community to integrate its concern for Israel into the life of faith and practice to which they are summoned by the Holy One of Israel.

14. Cf. <www.shalomctr.org>. 
In Vancouver a group of secular Jews publish a progressive Jewish review called Outlook that supports the State of Israel but engages in an extended critique of its policies. In its editorials, Outlook opposes the occupation and the settlement. The review promotes a critical outlook on Canadian affairs and world politics from a democratic socialist perspective. It offers its pages to dissident Jews in Israel and North America.

Quite different is the Jewish Peace Fellowship that promotes a commitment to non-violence on theological grounds ${ }^{15}$. Like the other organisations mentioned above, the Jewish Peace Fellowship is in solidarity with the Jewish State but disagrees with its policies. The Fellowship is in touch with the Rabbis for Human Rights and other Jewish peace groups in Israel. A good introduction to the Jewish commitment to non-violence is the book The Challenge of Shalom, published by the Fellowship ${ }^{16}$.

The Tikkun Magazine, founded by Rabbi Michael Lerner, is a major publishing venture that tries to bring together progressive political reflection and the Jewish spiritual tradition ${ }^{17}$. Because he wants to overcome the alienation of the Left from religious resources, Michael Lerner also invites Christian authors who acknowledge the link between faith and social justice to write articles for his magazine. To promote the spiritual commitment to peace, justice and respect for the environment, Rabbi Lerner has created Tikkun Communities in several regions of the United States, bringing together Jews who love justice and seek to relate their political perspective to the revealed sources of faith and practice.

The following text is an example of Rabbi Lerner's theology. In it he deals with the topic of atonement for the feast of Yom Kippur in 2000.

TIKKUN MAGAZINE is urging Jews and Palestinians to atone for their actions in the past days. On the Jewish side, we are contacting rabbis and others and urging them to support silent vigils and fasting in protest of the excessive use of force by Israel. And we are asking them to include a special section of the Yizkor (memorial prayer for the dead) in memory of the Palestinians as well as Israelis who have lost their lives in the current flare up of violence in the struggle to end the occupation. And we are

15. See "Shalom: The Jewish Peace Letter" published by the Jewish Peace Fellowship, Box 271, Nyack, NY, 10960.

16. M. Polner and N. Goodman, eds., The Challenge of Shalom, Philadelphia, New Society Publishers, 1994.

17. Cf. <www.tikkun.org>. 
calling on Palestinians to take similar public actions of protest and atonement against those who are only responding with violence rather than seeking common ground. Yet we do not see these two as totally morally equivalent - the reality remains that the Palestinians have no army and are occupied by one of the most powerful military forces in the world $^{18}$.

Michael Lerner's recent book ${ }^{19}$ offers a presentation of the Middle East conflict seen through the eyes of Jews and the eyes of Palestinians. Lerner records with sympathy the Jewish drama of a persecuted people seeking refuge in new land without sufficient respect for the local population, and the Palestinian story of a colonized people seeking to protect its cultural identity against westernization without sufficient generosity toward the arriving refugees. The author wants to overcome the tendency on both sides to demonize the opponent, remain ignorant of their true history, and refuse to recognize the moderate voices in the other camp. The author is fully aware that in the present political climate many Jews will be shocked by his critical analysis of Israeli policies and many Palestinians will feel that he does not have sufficient sympathy for their struggle. The purpose of his book is to bring the moderates of the two sides into dialogue and invite the wider community, including Christians, to join this conversation.

Can there be respectful conversation on a topic that stirs up the emotions? A few months ago, a noisy conflict between Jewish and Palestinian students at Montreal's Concordia University erupted into violence. In response to the violent incident, a small group of Jewish and Arab citizens created an association of Moderates, people from different sides, committed to justice and human rights, who wish to engage in civilised conversation about their political aims ${ }^{20}$. One concern of the Moderates is to prevent the Middle East conflict to disturb the peace between people of Jewish, Muslim or Arab origin living in Canada. To foster the spirit of moderation, the Moderates have organised lectures

18. M. Lerner, "Atonement in the Month of Awe," on the website of The Shalom Center, <www.shalomctr.org/index.cfm/action/read/section/HOLI/article/ peace15.html>.

19. M. Lerner, Healing Israel/Palestine: A Path to Peace and Reconciliation, San Francisco, Tikkun Books, 2003.

20. The website of the Moderates is <www.cemod.ca>. 
and panel discussions at Concordia University, including interreligious conversation among Jews, Christians and Muslims.

However difficult it may be, interreligious dialogue, including Jewish-Christian dialogue must go on. Allow me at the end of this article to quote from the Ten Commandments of Peace formulated by Pope John Paul II in January 24, 2000:

We commit ourselves to educating people to mutual respect and esteem, in order to help bring about a peaceful and fraternal coexistence between people of different ethnic groups, cultures and religions.

We commit ourselves to fostering the culture of dialogue, so that there will be an increase of understanding and mutual trust between individuals and among peoples, for these are the premise of authentic peace.

We commit ourselves to frank and patient dialogue, refusing to consider our differences as an insurmountable barrier, but recognizing instead that to encounter the diversity of others can become an opportunity for greater reciprocal understanding ${ }^{21}$.

21. See The Ecumenist, 39 (Summer 2002) p. 1. 


\title{
RÉSUMÉ
}

Comment intégrer l'existence de l'État d'Israël à la théologie? Du côté juif, les points de vue de Fackenheim et Greenberg sont deux réponses contrastées à cette question - l'a. préférant le second. Du côté chrétien, et dans l'itinéraire personnel de l'a., une évolution en trois étapes se dessine: ferme soutien d'Israël sans aucune critique (avant la première Intifadah), solidarité avec le peuple d'Israël et les Palestiniens (première Intifadah), malaise croissant face à l'oppression vécue par les Palestiniens (seconde Intifadah). Même si les grandes institutions juives nord-américaines tendent à associer antisémitisme et critique de l'occupation / colonisation de la Palestine, il existe des organisations juives, surtout en Israël, qui s'opposent à l'occupation et offrent des réflexions critiques à l'égard de la politique de l'État hébreu.

\begin{abstract}
How to integrate the State of Israel into theology? On the Jewish side, an important contrast exists between the views of Fackenheim and Greenberg, the latter having the sympathy of the author. On the Christian side, the author observes a development in three steps, confirmed by his own critical reflection: uncritical support of Israel (prior to the first Intifadab), solidarity with the people of Israel and the Palestinians (the first Intifadab), increasing discomfort over the oppression of the Palestinians (second Intifada). Even if the major Jewish institution in North America tend to suspect of anti-Semitism voices that denounce the occupation and the colonisation of Palestine, there are many Jewish organisations, especially in Israel, that oppose the occupation and severely criticise the policies of the Israeli government.
\end{abstract}

(c) Revue Théologiques 2003. Tout droit réservé. 